\title{
Trijalistička reforma Austro-Ugarske u časopisima slovenskih liberala iz Trsta i Gorice
}

Rad predstavlja ideju federalizacije Habsburške Monarhije, točnije formiranja njezine treće državne jedinice prije Prvoga svjetskog rata kroz objave slovenskih liberalnih časopisa iz Trsta i Gorice. Autor iznosi širi kontekst u okviru kojega se koncept oblikovao, a zatim analizira komentare predmetnih časopisa o reakcijama različitih političkih skupina, njihovim ambicijama te nacionalnim tenzijama koje su se manifestirale u kontekstu rasprave o trijalizmu. Polazišna je teza da je trijalizam prije svega bio austrijski pokušaj uvođenja treće habsburške jedinice da bi se smanjila snaga Ugarske. Krajem 19. i na početku 20. stoljeća većina Slovenaca i Hrvata, uključujući i slovenske liberale iz Trsta i Gorice, podržavala je tu ideju radi vlastite političke emancipacije. S druge strane Mađari, Talijani, dio Nijemaca i Srbi u tom su konceptu vidjeli prijetnju vlastitim nacionalnim interesima. Daljnjim su razvojem ideje, uslijed austrijskih ambicija zadovoljavanja Talijana, Trst i Gorica izuzeti iz zamišljene treće jedinice, što je izazvalo napetosti i u hrvatsko-slovenskim odnosima i u slovenskoj političkoj sferi između liberala i konzervativaca. Slovenski tršćanski i gorički liberali počinju se okretati ideji širega federalizma, to jest prema Habsburškoj Monarhiji s više jedinica, a u kontekstu južnoslavenskih odnosa sve se više okreću prema srpskim državnim vizijama.

Ključne riječi: slovenski liberali, federalizam, trijalizam, Habsburška Monarhija, Austrijsko primorje

\section{Nositelji ideje i otpora trijalizmu}

Krajem 19. stoljeća Austro-Ugarska je bila suočena s brojnim problemima, a rješavanje nefunkcionalne unutarnje organizacije bilo je od strateške važnosti za sam opstanak države. Reforme birokratskoga aparata nisu bile dovoljno brze ni 
učinkovite da bi Monarhija mogla jednakopravno sudjelovati u ekonomskoj utrci s konkurentnim europskim velesilama. ${ }^{1}$ Unutarnja je nestabilnost pogoršavala položaj Monarhije i u međunarodnim odnosima, a slabost Monarhije odražavala se i u nesposobnosti kroćenja manjih država u njezinu susjedstvu. Tako je primjerice carinski rat sa Srbijom 1906. uzrokovao dodatno usporavanje austrougarske ekonomije, a upozoravao je i na mnogo veće probleme. Soča, slovenski liberalni časopis iz Gorice, u to je vrijeme naime objavila da je carinski rat između Austrije i Srbije zapravo priprema za opći rat, u kojem bi i Francuska i Njemačka mogle djelovati u korist Srbije protiv austrijskih interesa na Balkanu. ${ }^{2}$ Srbija, čiji je odnos prema Beču bio negativan od povratka Karađorđevića na srpsko prijestolje, doista je dobila podršku Francuske ${ }^{3}$ i Njemačke, koje su otvorile tržište za srpsku robu i tako spriječile teške posljedice austrougarskoga bojkota. Iako se činio prirodnim saveznikom Habsburške Monarhije, njemački je nacionalizam dodatno suzio manevarski prostor za austrougarsku diplomaciju. Nadalje, Italija, formalni saveznik Habsburgovaca od 1882., ponašala se na sličan način, potičući iredentističke težnje habsburških Talijana. Istodobno je prijetnja carske Rusije bila donekle manja jer se još oporavljala od poraza u ratu s Japanom, no nikako nije bila zanemariva njezina ambicija većega angažmana na Balkanu. Znatna je pozornost morala biti posvećena i Osmanskom Carstvu. Ono doduše nije bilo izravna prijetnja, ali je pad sultanove moći implicirao pitanje tko će zauzeti područje toga umirućeg carstva. S habsburškoga su aspekta te okolnosti povećavale važnost rješavanja unutarnjega uređenja da bi se moglo aktivnije krenuti u osiguravanje vitalnih gospodarskih putova na jugoistoku Europe.

Habsburški pomak prema aktivnijoj politici napravljen je imenovanjem Aloisa Aehrenthala na mjesto ministra vanjskih poslova u listopadu 1906. godine. Taj je karijerni diplomat budućnost države vidio u višeentitetskoj političkoj formaciji u kojoj bi i mali narodi mogli zadovoljiti vlastite nacionalne ambicije. Glavni cilj te strategije bilo je uključivanje novih federalnih jedinica u politički život Habsburške Monarhije, što bi donekle umanjilo opterećenost i važnost relacije Beč - Budimpešta te smanjilo ugarsku mogućnost veta i posljedično ojačalo položaj Austrije, koja bi u federalnom uređenju preuzela ulogu moderatora. ${ }^{4} \mathrm{U}$ skladu s tom strategijom Aehrenthalov je prvi korak imao za cilj uređenje juga Monarhije, ponajprije osnaživanje onih političkih snaga koje su bile usmjerene ujedinjenju

\footnotetext{
1 Ifor L. Evans, „Economic Aspects of Dualism in Austria-Hungary”, The Slavonic and East European Review 6 (1928), br. 18: 529-542.

2 Soča (Gorica), 31. 1. 1906., 4.

3 John R. Lampe, Yugoslavia as history. Twice there was a country, second edition (Cambridge: Cambridge University Press, 2000), 85; Đorđe Stanković, Nikola Pašić, saveznici i stvaranje Jugoslavije (Beograd: Nolit, 1984), 24.

4 Solomon Wank, „Aehrenthal's Programme for the Constitutional Transformation of the Habsburg Monarchy. Three Secret 'Mémoires'”, The Slavonic and East European Review 41 (1963), br. 97: 521-522.
} 
Hrvatske, Slavonije i Dalmacije u jedinstvenu jedinicu sa središtem u Zagrebu. Dodavanjem Bosne i Hercegovine (BiH), koju je Austro-Ugarska anektirala 1908., mogla bi se formirati treća federalna jedinica, koja dugoročno vrlo vjerojatno ne bi bila i posljednja u Aehrenthalovu federalnom konceptu Habsburške Monarhije. Aehrenthal, dakako, nije bio sâm kada je u pitanju ideja trijalizma. Veći je teret očekivanja bio na budućem vladaru Monarhije, Franji Ferdinandu, koji je također zagovarao federalni koncept države s najmanje tri jednakopravne jedinice u kojoj će Austrija, odnosno dinastija Habsburg, imati ulogu koordinatora. U njegovoj su percepciji hegemonistički planovi njemačkih liberalnih i nacionalnih političkih grupacija, kao i slični pokreti među Mađarima, bili najveća prijetnja za Monarhiju. Planom osnaživanja manjih naroda u Ugarskoj, u prvom redu Hrvata, Franjo Ferdinand stekao je reputaciju njihova zaštitnika. Slično kao kod Aehrenthala, Ferdinandova je vizija bila federacija sastavljena od jedinica nacionalnoga karaktera gdje bi vitalni državni resori trebali ostati u domeni austrijskoga centra. I Karl Schwarzenberg mogao se ubrojiti među pristaše federalizma. Godine 1910. upravo je on najegzaktnije definirao Ferdinandovu viziju reorganizacije države: „Ne mogu izgovoriti riječ trijalizam bez dodatka da se zalažem za trijalističko uređenje samo ako izuzmemo zajedničke resore iz pojedinih dijelova Carstva te ih objedinimo i spojimo u zajedničko tijelo. ... trijalizam, koji bi mogao biti ... zlatni put između centralizma i federalizma."

Hrvati su prema shvaćanju Franje Ferdinanda imali iste političke neprijatelje kao Habsburgovci, prije svega mađarske nacionaliste i sljedbenike velikosrpske ideje. Vjerovao je da Hrvatska, Slavonija, Dalmacija i BiH prirodno pripadaju zajedno. Zbog svojih zasluga u očuvanju Monarhije u 19. stoljeću upravo bi Hrvati trebali biti nagrađeni ujedinjenjem tih pokrajina i većom autonomijom na račun Mađara. ${ }^{6}$ Njegov je dakle plan bio stvoriti jedinicu s hrvatskim jedrom koja bi se trebala nazvati Kraljevina Ilirija. Njoj bi se pripojili i slovenski teritoriji, a Vojvodina bi ostala mađarska. Cilj realizacije ilirske ideje bio je znatno umanjiti mogućnost srpskih pretenzija na teritorij Habsburške Monarhije. Štoviše, habsburški Južni Slaveni trebali su utjecati na Srbe da i oni traže svoju budućnost unutar federalnoga habsburškog carstva, pogotovo jer su Hrvati i Slovenci u očima Franje Ferdinanda bili „kulturno daleko nadmoćniji od Srba i Crnogoraca”.7 To je u isto vrijeme trebalo povećati ne samo hrvatsku nego i slovensku odanost Monarhiji. Tršćanski slovenski liberalni časopis Edinost oduševljeno je pisao o tome kako bi unutar Ilirije i Slovenija imala status pokrajine, a osim Kranjske obuhvaćala bi

\footnotetext{
5 Andrej Rahten, Slovenska ljudska stranka v Dunajskem parlamentu. Slovenska parlamentarna politika v Habsburški monarhiji 1897-1914 (Celje: Cenesa, Založba Panevropa, 2001), 109-110.

6 U to je nekoliko puta uvjeravao i hrvatskoga plemića Marka Bombellesa govoreći mu: „Recite vašim Hrvatima, neka samo još ovaj puta sačuvaju svoju tradicionalnu vjernost. Čim stupim na prijestolje, ispravit ću sve nanesene im nepravde.” Ivo Pilar, Južnoslavensko pitanje. Prikaz cjelokupnog pitanja (Varaždin: Hrvatska demokratska stranka, Podružnica Varaždin, 1990), 364.
}

7 Rahten, Slovenska ljudska stranka v Dunajskem parlamentu, 116. 
i Goricu, Trst sa sjevernom Istrom, Korušku i Štajersku južno od rijeke Drave. ${ }^{8}$ Vizija takozvane belvederske grupe bila je dakle osmišljen državni koncept $s$ tri federalne jedinice sa svojim centrima u Beču, Budimpešti i Zagrebu.

Nisu svi s oduševljenjem gledali na unutarnju teritorijalnu reformu. Najveća prepreka za provedbu federalizacije bio je postojeći sustav odlučivanja, koji je zahtijevao pristanak Budimpešte za takve dalekosežne reforme. Unutarnji spor o statusu pripojene $\mathrm{BiH}$ pokazao je da je dobivanje potpore Mađara doista golema prepreka. Nepripremljenost Monarhije za apsorpciju novoga područja odrazila se u kolapsu agrarne reforme i činjenici da je BiH svoj ustav dobila tek 1910. godine. $S$ jedne bi strane pripajanje austrijskom ili ugarskom dijelu značilo znatno narušavanje unutarnje ravnoteže. $S$ druge pak strane podjela prema kojoj bi Bosna pripadala Ugarskoj, a Hercegovina Austriji bila je neprihvatljiva jer je implicirala nezadovoljstvo jednoga dijela Mađara i praktički svih Južnih Slavena, prije svega Hrvata, no i samih bosanskohercegovačkih Srba. Aehrenthal je u potrazi za prevladavanjem neslaganja predložio subdualistički oblik Monarhije, za koji je intimno smatrao da bi bio samo privremeno rješenje, odnosno jedan od koraka u njegovoj federalističkoj strategiji. Njegov prijedlog iz 1907. predviđao je pripajanje BiH Hrvatskoj i Slavoniji zajedno s Dalmacijom, a to bi područje tada bilo poseban dio unutar ugarskoga dijela Monarhije. U tom bi se subdualističkome modelu svi hrvatski teritoriji sa središtem u Zagrebu ujedinili u sklopu mađarske krune sv. Stjepana. To bi značilo smanjenje austrijskoga dijela Monarhije jer bi Dalmacija pripala Ugarskoj, no Austrija bi sačuvala pristup Jadranu u Istri. Međutim, prema Aehrenthalovim predviđanjima, proširenje ugarskoga dijela Monarhije na dugi bi rok ipak dovelo do formiranja treće federalne jedinice jer bi se udio Južnih Slavena u Ugarskoj povećao do te mjere da Budimpešta više ne bi mogla zaustaviti njihove emancipacijske težnje. Stoga to „neće dovesti do jačanja mađarske države, nego će Monarhiju dovesti na put koji je vjerojatno najprikladniji za njezin razvoj". 9

Aehrenthalov plan nije impresionirao Mađare. Većina je odbacila novi subdualistički koncept i tražila neposredno pripojenje BiH Ugarskoj. ${ }^{10} \mathrm{U}$ početku su se pojedinci iz mađarske političke sfere, poput ministra financija Istvána Buriána, čak i zalagali za Aehrenthalov prijedlog, no ubrzo se i sam Burián predomislio i u travnju 1908. predložio caru zajedničko austrougarsko upravljanje BiH. Međutim, ni to nije naišlo na odobravanje većine Mađara. Prema pisanju njihovih novina, ta je ideja rođena u Beču s ciljem oduzimanja Mađarima kontakta s Jadranskim morem. Tršćanska Edinost i gorička Soča u tom su razdoblju često citirale i negativno komentirale mađarski tisak, u prvom redu objave časopisa $\mathrm{Aj} U \mathrm{Uj}$ -

\footnotetext{
8 Edinost (Trst), 24. 6. 1909., 2.

9 Wank, „Aehrenthal's Programme”, 521.

10 Mađarski su nacionalisti tu težnju opravdali činjenicom da je u srednjem vijeku mađarski kralj bio i kralj Rame (Rahten, Slovenska ljudska stranka v Dunajskem parlamentu, 76-77).
} 
sag, koji je smatrao da bi trijalizam isključio mađarski utjecaj na ovom području Monarhije. ${ }^{11}$ Liberalne slovenske tiskovine isijavale su teze mađarskih novina $\mathrm{u}$ Hrvatskoj, koje su pokušavale proširiti stav da će jedinica Južnih Slavena uzrokovati političke i ekonomske probleme samim Hrvatima i tako zapravo smanjiti kvalitetu života njih i svih Južnih Slavena u Monarhiji. Prema toj tezi, Mađari su bili brojniji, kulturno razvijeniji i ekonomski bogatiji, ${ }^{12}$ stoga je njihovo vodstvo bilo apsolutno neophodno za tobožnju dobrobit Južnih Slavena. ${ }^{13}$ Slična je retorika korištena i u tiskovinama austrougarskih Talijana, s tom razlikom da su njihovi mediji prenosili da je trijalizam usmjeren u prvom redu protiv njih $\mathrm{s}$ ciljem slavenske dominacije u Dalmaciji i Austrijskom primorju te da je to ujedno i „slavenski napad na Trst”. ${ }^{14}$

\section{Percepcija stavova Hrvatsko-srpske koalicije}

Srž trijalističke ideje bila je državna jedinica s centrom u Hrvatskoj, stoga su njezini kreatori oslonac tražili u hrvatskoj državotvornoj ideji, točnije u institutu hrvatskoga povijesnoga državnog prava. Unatoč tomu što je ideja uključivala dodatnu političku emancipaciju Hrvata, na hrvatskoj su političkoj pozornici ipak postojali različiti stavovi o trijalističkim planovima. Iako su ideju o većoj autonomiji habsburških Južnih Slavena načelno pozdravile sve stranke, u Zagrebu su formirane dvije političke grupacije različitih vizija. U kontekstu „novoga političkoga kursa" i rezolucija donesenih najprije u Rijeci, a potom nakon dogovora s hrvatskim Srbima u Zadru, formirana je Hrvatsko-srpska koalicija (dalje: Koalicija). ${ }^{15} \mathrm{U}$ svojim nastojanjima da ujedini Hrvatsku, Slavoniju i Dalmaciju Koalicija je zagovarala strateško partnerstvo sa Srbima i Mađarima nasuprot Austriji. Radi dobivanja srpske potpore novi je hrvatski politički smjer počeo odstupati od koncepta hrvatskoga državnog prava koje bi pokrivalo i $\mathrm{BiH}$. Čelnici „novoga kursa” nisu to ni pokušavali sakriti, što je vidljivo iz govora Frana Supila u Hrvatskom saboru 25. veljače 1907. godine: „Kad smo toga svjesni, da je naš zadatak, da budemo Balkanu zaštitni bedem a ne most, preko kojeg će onamo prelaziti neprijateljski pohodi, računati nam je u prvom redu s našom srpskom braćom ... Priznajući Srbe, mi smo ih ponovno pridobili za misao utjelovljenja Dalmacije. ... Ali ne znamo, što se zbiva s Bosnom i Hercegovinom. ... I ako sreća dade, da Bosna i Hercegovina izađu iz okvira Monarhije, sasvim je prirodno, da će svaki pravi i pošteni Hrvat radije gledati, kako pripada bratskim

\footnotetext{
11 Edinost, 11. 5. 1909., 1.

12 Soča, 20. 7. 1909., 3.

13 Edinost, 7. 8. 1909., 2.

14 Soča, 27. 12. 1910., 1.

15 Igor Ivašković, „The Implications of the New Course Strategy”, Politička misao 56 (2020), br. 3-4: 224-230.
} 
Srbima, umjesto strancima, kad već ta Bosna ne može biti hrvatskom."16 Označavanje Austrijanaca (i Nijemaca) neprijateljima i istodobno stavljanje Hrvatske na stranu ,istoka” bilo je dramatičan pomak u hrvatskom političkom životu. Ove Supilove riječi, prije svega uvjetovanje „sreće” $\mathrm{BiH}$ povlačenjem Austrijanaca, a samim time i prepuštanjem BiH Srbiji, odražavale su srpski geostrateški plan. ${ }^{17}$ Posljedično je Koalicija dobila punu pozornost pojedinih srpskih tiskovina, a u tom kontekstu mogu se pronaći i neki afirmativni stavovi o spajanju Dalmacije s Hrvatskom i Slavonijom. ${ }^{18}$ Tijekom aneksijske kampanje dio hrvatskih članova Koalicije ipak je počeo ponovno naglašavati koncept hrvatskoga državnog prava i u tom kontekstu pripadnost $\mathrm{BiH}$ trojednoj hrvatskoj državi, što je bila indicija da južnoslavenski koncept unutar Koalicije ipak još nije konačno definiran jer je znatan dio članstva tražio putove prema hrvatskoj političkoj emancipaciji bez obzira na srpske ciljeve. Istovremeno dio pripadnika Koalicije, iako je podržavao ideju trijalizma, nije vjerovao u mogućnost njezine realizacije, misleći da je to samo trik bečke političke oligarhije. ${ }^{19}$ Taj se dio Koalicije postupno odrekao trijalizma i krenuo rješenje tražiti u široj federalizaciji Habsburške Monarhije. Treći dio Koalicije djelovao je pak protiv ideje hrvatskoga ujedinjenja. U strahu da će im Hrvati okrenuti leđa u ključnom trenutku, odnosno kad postignu ujedinjenje hrvatskih provincija, dio Srba počeo je odstupati od sukcesivnoga pogleda na rješavanje južnoslavenskoga pitanja. Srbi su naime bili uvjereni da su hrvatski članovi Koalicije, unatoč očitoj spremnosti da BiH prepuste Srbima, tiho računali s tim da je to ionako irelevantno pitanje jer su se nadali da Beč nikada neće dopustiti takav ishod bez obzira na formalni hrvatski stav o pripadnosti $\mathrm{BiH}$. Posljedično su trijalizam i koncept državnoga prava gurani u okvir njemačkoga geostrateškog nacrta Balkana te predstavljeni kao najveći neprijatelji jugoslavenske ideje.

Primorski Slovenci isprva su upravo u Koaliciji vidjeli recept za rješavanje hrvatsko-srpskih sporova i uspjeh Južnih Slavena na putu k federalnoj Monarhiji s južnoslavenskom jedinicom. ${ }^{20}$ Koaliciju su očito shvaćali kao formulu za pre-

\footnotetext{
16 Pilar, Južnoslavensko pitanje, 351.

17 Hrvatsko-srpski sporazum sa srbijanskoga stajališta trebao je biti ključan za dobivanje šire političke potpore među Južnim Slavenima u Habsburškoj Monarhiji. Prema riječima Nikole Pašića, čelnika Narodne radikalne stranke, prirodna posljedica sporazuma između Srba i Hrvata trebala bi biti buduća dominacija pravoslavnih Srba u južnoslavenskim političkim pokretima jer su Srbi već imali dvije neovisne države (Srbiju i Crnu Goru), koje su uspjele sačuvati više slavenskih karakteristika u nacionalnoj kulturi od habsburških Slavena, a pridobile su i veću međunarodnu potporu Habsburgovcima konkurentnih velikih sila (Stanković, Nikola Pašić, 22-23).

18 Jovo Bakić, Ideologije jugoslovenstva između srpskog i hrvatskog nacionalizma 1918-1941 (Zrenjanin: Gradska narodna biblioteka „Žarko Zrenjanin”, 2004), 165-167.

19 Takav je odnos bio vidljiv u komentarima dubrovačkoga lista Crvena Hrvatska (Pero Depolo, „Političke struje u Dubrovniku i aneksija Bosne i Hercegovine /II. dio/", Anali Dubrovnik 38 /2000/: 250).

20 Edinost, 8. 1. 1910., 1-2.
} 
vladavanje vjerskih razlika, što je bio pojednostavnjeni pogled na južnoslavenski problem. On je ignorirao činjenicu da je pravo na državu sa svojom nacionalnom većinom bilo glavni motiv i srpskim i hrvatskim političkim grupacijama, a natjecanje između različitih pogleda očito se nastavilo i unutar Koalicije. Međutim, ubrzo je postalo jasno da je jedna strana stekla prednost u toj bitci. Unutarnji sukob u Koaliciji ipak je, čini se, bio riješen do 1910., a javni istupi njezinih čelnika nisu ostavljali previše sumnji u to koji je koncept jugoslavenstva prevladao u njoj. Frano Supilo održao je naime u Pragu 28. studenog 1910. znakovit govor: „Oslanjanje na djela hrvatskih kraljeva i srpskih careva nerazumijevanje je povijesti. Kao državnici, oni su širili opseg svojih zemalja, ali nisu mogli prejudicirati opseg današnjih hrvatskih i srpskih političara. Jezik je zajednički, isti je; a tko danas vjeru uzima kao prepreku zajednici, pravi budalu od sebe. Slovenci također nisu ništa drugo nego dio jedinstvenog jugoslavenskog naroda." ${ }^{21}$ Ovaj očiti otklon od koncepta povijesnoga državnog prava govorio je o porazu kroatocentrične struje unutar Koalicije. Već je u prvom dijelu govora Supilo označio klerikalizam kao drugu temeljnu prepreku srpsko-hrvatsko-slovenskom jedinstvu. Štoviše, prema Supilu, upravo je klerikalizam bio stup postojećega habsburškoga državnog sustava, koji je po njegovu mišljenju bio krajnje nepovoljan za sve Južne Slavene: „Jugoslaveni su umjetno podijeljeni u razne državne skupine, tako da pojedinci ne mogu učiniti ništa, no zajedno bi mogli puno. U austrougarskoj monarhiji dualizam skrbi za tu podijeljenost. ... Osnova svake naše politike trebala bi biti sljedeća: svijest da su Slovenci, Hrvati i Srbi jedan narod! ... Da bismo postigli slobodu, moramo se boriti protiv klerikalizma!"22 Na prvi se pogled teze o južnoslavenskom reciprocitetu i kritika dualističkoga sustava nisu bitno razlikovale od pogleda onoga dijela Slovenaca i Hrvata koji su zagovarali trijalizam, no Supilo je u posljednjem dijelu svojega govora ponudio potpuno drugačiju ideju reorganizacije države: „Situacija u kojoj se mi Jugoslaveni nalazimo slična je tamnici, zatvoru. ... U Austriji su danas njemački i mađarski narod nacije prvog reda, svi smo mi ostali narodi drugog reda. Ako se obistini trijalizam, Jugoslaveni bi postali prvorazredna nacija, dok bi Česi, Poljaci, Rusi, Rumunji, koji su kulturno, gospodarski i politički jači od nas, ostali drugorazredni narodi." ${ }^{23}$ Od 1910. nadalje Supilo je tako zastupao radikalne promjene, pa čak i zazivao formiranje južnoslavenske države izvan Habsburške Monarhije. Koalicija je stoga trijalističku ideju označavala kao habsburško-klerikalni pokušaj produbljivanja razlika između Slovenaca i Hrvata s jedne i Srba, odnosno Jugoslavena s druge strane. U skladu s tim čak je i mađarski tisak Koaliciju predstavljao kao hrvatskim jezikom govorećim Jugoslavenima, koji nemaju osjećaj hrvatskoga zajedništva. ${ }^{24}$ Može se

\footnotetext{
${ }^{21}$ Edinost, 2. 12. 1910., 1.

22 Edinost, 2. 12. 1910., 1-2.

23 Edinost, 2. 12. 1910., 2.

24 Mislav Gabelica, „Političke prilike u Banskoj Hrvatskoj na početku Prvog svjetskog rata”, Društvena istraživanja 23 (2014), br. 1: 179.
} 
dakle zaključiti da je politika „novoga kursa” iz Rijeke i Zadra ipak preživjela unutarnje nesuglasice. Spor u Koaliciji završio je kristalizacijom jugoslavenskoga koncepta, koji je bio suprotan trijalističkom kroatocentričnom rješenju unutar Habsburške Monarhije te je zazivao i uključenje Srbije kao središta buduće države.

Liberalni slovenski časopisi iz Trsta i Gorice nisu bili skloni opoziciji Koalicije. Meta kritika još iz vremena razvoja politike „novoga kursa” najčešće je bila Čista stranka prava Josipa Franka, ${ }^{25}$ koja je ideju trijalizma prihvatila raširenih ruku, istovremeno odbijajući bilo kakve koncesije hrvatskim i bosanskohercegovačkim Srbima jer je smatrala da Srbi ne mogu biti politički narod na područjima koja povijesno pripadaju hrvatskoj državi. ${ }^{26}$ Ipak, ta je politička stranka predstavljala samo dio pravaša, koji su se podijelili na pristaše Koalicije i one koji su bili protiv nje. Veći se dio ipak našao u ujedinjenoj Stranci prava, koja se do početka Prvoga svjetskog rata potpuno podredila ciljevima Koalicije. ${ }^{27}$ Neskladnost oporbenih stavova dopunjavao je Stjepan Radić, tada zvijezda u usponu u hrvatskoj politici, koji je odbacio politiku „novoga kursa” kao novi oblik „mađaronstva”, a status Srba po podrijetlu priznavao samo srpskim stanovnicima Srijema, dok je za ostale hrvatske Srbe smatrao da je njihov osjećaj plod političke i vjerske propagande. ${ }^{28}$ No Radić nije bio pouzdan partner nijednoj drugoj oporbenoj političkoj grupaciji. Bosanskohercegovački Hrvati na aneksiju su pak gledali kao na oslobođenje ${ }^{29}$ te su upozoravali na opasnost od prepuštanja BiH Srbiji. Nisu simpatizirali ni ideju autonomne $\mathrm{BiH}$, što je bio predložio Burián, a priželjkivali bosanskohercegovački Srbi, a još su manje bili skloni ideji spajanja BiH sa Srbijom i Crnom Gorom. ${ }^{30}$ U veljači 1908. bosanskohercegovački Hrvati zatražili su i od samoga Aehrenthala pripojenje BiH Trojednoj Kraljevini. No nisu svi Hrvati u BiH imali jednake pozicije. Već je prije aneksije Starčevićeva stranka prava pokušavala privući bosanskohercegovačke muslimane, stoga kritizira političko djelovanje Josipa Stadlera te podupire liberalniji pokret pod vodstvom Nikole Mandića. Nakon aneksije počinje se približavati politici Koalicije i napušta ideju ujedinjenja $\mathrm{BiH}$ s Hrvatskom. ${ }^{31}$

\footnotetext{
25 Edinost, 8. 10. 1905., 1; Edinost, 17. 10. 1905., 2.

26 Ivo Banac, Nacionalno pitanje u Jugoslaviji: porijeklo, povijest, politika (Zagreb: Globus, 1988), 92.

27 Ivan Bulić, „Politika Hrvatsko-srpske koalicije uoči Prvoga svjetskog rata 1907. - 1913.”, Časopis za suvremenu povijest 44 (2012), br. 2: 421.

28 Branka Boban, „Mladi Stjepan Radić o Srbima u Hrvatskoj i odnosima Hrvata i Srba”, Radovi 28 (1995), br. 1: 131.

29 Depolo, „Političke struje u Dubrovniku (II. dio)”, 245.

30 Pilar, Južnoslavensko pitanje, 354.

31 Stjepan Matković, Čista stranka prava 1895. - 1903. (Zagreb: Hrvatski institut za povijest, 2001), 119-122.
} 


\section{Slovenska očekivanja i strahovi}

Slovenci su bili uključeni u trijalističke planove, štoviše i sami su bili vrlo zainteresirani za uključenje u treću habsburšku jedinicu, no njihov je specifičan geopolitički položaj uzrokovao brojne dileme. Na jednoj su strani sa slovenskoga stajališta poteškoće proizlazile iz činjenice da su Slovenci imali periferan položaj među Južnim Slavenima te su bili u izravnom kontaktu s mnogo brojnijim talijanskim i njemačkim (austrijskim) narodom. Upravo su u Trstu ${ }^{32}$ i Gorici ${ }^{33}$ Slovenci bilježili povoljan demografski trend, a činjenica da je to uključivalo strateški najvažniju jadransku luku povećala je uloge u slovenskoj borbi za viši stupanj političke emancipacije. To je područje također bilo specifično u okviru nadmetanja među slovenskim političkim strankama. Naime, u slovenskom geopolitičkom središtu, to jest u Kranjskoj s iznimkom Ljubljane, dominirala je konzervativna Slovenska pučka stranka (slov. Slovenska ljudska stranka - SLS), a u Gorici i Trstu, uz dakako Ljubljanu, među Slovencima su najveću potporu imali slovenski liberali u okviru Narodno-napredne stranke (NNS). I dok su u Ljubljani nastupali s pozicije vlasti, ${ }^{34}$ u primorskim područjima NNS je djelovao kao opozicija talijanskoj većini, ${ }^{35}$ koja se u Gorici oslanjala i na savezništvo sa slovenskim konzervativcima. ${ }^{36}$

U vrijeme aneksije $\mathrm{BiH}$ članovi SLS-a nisu imali dvojbi glede pripadnosti anektiranih područja. Stranka je naime održavala čvrste veze s hrvatskim strankama koje su se zalagale za koncept hrvatskoga povijesnoga državnog prava. U nastojanju da subjektiviziraju Slovence i spriječe daljnju germanizaciju slovenskih područja, pokušali su slovenske teritorije povezati upravo s hrvatskim državotvornim konceptima. Činjenica da su hrvatsko državno pravo priznavali i austrijski i mađarski političari išla im je u prilog. Svi istaknuti članovi SLS-a djelovali su

\footnotetext{
32 Prema popisu iz 1910., približno 51,9\% stanovnika koristilo je talijanski jezik, 24,8 \% slovenski, 5,2 \% njemački, 1,1 \% „srpskohrvatski”, 0,3 \% neki drugi jezik, a bilo je čak $17 \%$ stranih državljana. „Spezialortsrepertorium für das österreichisch-illyrische Küstenland: bearbeitet auf Grund der Ergebnisse der Volkszählung vom 31. Dezember 1910 / herausgegeben von der K. k. statistischen Zentralkommision", Spezialortsrepertorium der österreichisch Länder 7 (Beč: K. k. Hof- und Staatsdruckerei, 1918); Lampe, Yugoslavia as history, 75; Jože Pirjevec, Trst je naš! Boj Slovencev za morje (1948-1954) (Ljubljana: Nova revija, 2007), 19.

${ }_{33}$ Aleksej Kalc, „Vidiki razvoja prebivalstva Goriške-Gradiške v 19. stoletju in do prve svetovne vojne", Acta Histriae 21 (2013), br. 4: 700.

${ }^{34}$ Ivan Hribar bio je uvelike najvažnija politička figura toga razdoblja u Ljubljani. Održavao je brojne kontakte s hrvatskim političarima te bio jedan od najgorljivijih zagovornika najprije hrvatsko-slovenskoga, a potom i širega južnoslavenskog ujedinjenja. Vidi: Stjepan Matković, Premili Ivane: korespondencija Ivana Hribara s hrvatskom elitom (Zagreb: Hrvatski institut za povijest, 2016).

${ }_{35}$ O položaju Slovenaca u Trstu vidi: Igor Ivašković, „,Geopolitički zaokret liberalnih slovenskih krugova u Primorskoj pred Prvi svjetski rat", Časopis za suvremenu povijest 52 (2020), br. 1: 194-198.

${ }^{36}$ O položaju slovenskih liberala u Gorici vidi: Andrej Gabršček, Goriški Slovenci - narodne, kulturne, politične in gospodarske črtice, knj. 2: Od leta 1901 do 1924 (Ljubljana, 1934).
} 
u skladu s tom strategijom, uključujući Janeza Evangelista Kreka, koji je 18. srpnja 1907. izjavio: „Imamo zapisana prava biti jedno s Hrvatskom. I na temelju tih prava izjavljujemo da nikada neće uspjeti odvratiti Slovence od zaštite prava Hrvatske, Slavonije i Dalmacije." ${ }^{37}$ Oslanjanje na hrvatsko državno pravo i trijalistički koncept činilo se u to vrijeme kao jedina strategija koja je mogla odvojiti slovenske zemlje od njemačkih područja. Očekivalo se da bi upravno središte buduće državne jedinice u Zagrebu moglo umanjiti i utjecaj talijanskih iredentista, pa je isprva trijalizam bio prihvaćen s odobravanjem i među liberalnim primorskim Slovencima. Narodno-napredna stranka u početku je, slično kao SLS, pokušavala potaknuti ujedinjenje Južnih Slavena oko Hrvata. U određenom trenutku u kasnom 19. stoljeću, pod vodstvom Ivana Tavčara, bila je čak i vodeća slovenska stranka u povezivanju s hrvatskom Strankom prava. Još dvadeset godina prije same aneksije $\mathrm{BiH}$ tršćanska je Edinost u tom kontekstu objavila: „Mnogi Slovenci još uvijek sanjaju o ujedinjenoj Sloveniji. ... No slabi rezultati posljednjih godina trebaju nas uvjeriti da smo mi Slovenci sami preslabi da bismo takvo što izvojevali. ... Najučinkovitija pomoć bit će ako se udružimo s Hrvatima i Bošnjacima. ... onda ni srpska kraljevina nema uvjeta za zaseban opstanak: da polovina Srba bude u kraljevini, a polovina u Austriji, to nema smisla. Veća i jača slovensko-hrvatsko-bosanska država prirodnom će silom kraljevinu privući k sebi." ${ }^{38}$ Isti članak nastavlja s tvrdnjom da za Slovence ne postoji alternativa, no, što je još intrigantnije, Edinost se jasno opredjeljuje tko bi trebao igrati vodeću ulogu u formiranju države Južnih Slavena: „Međutim, ako Austrija ne ujedini Bosnu i Hrvatsku, prije ili kasnije će ju izgubiti. Srbi ju smatraju svojim nasljeđem i samo će čekati povoljnu priliku da ju otmu. To bi bilo loše za Hrvate i Slovence. ... Bez podrške Srba koji ne vole Hrvate, Hrvatska bi pala pod mađarsku ili njemačku prevlast. Mi Slovenci također se ne možemo nadati podršci Srba. Oni su samo Srbi, ne vole Hrvate ni Bugare, ne vole čak ni Ruse, ne vole mnogo slušati o slavenskom reciprocitetu. Samo sanjaju o svojem srpskom carstvu i misle da se Balkan mora pokoriti Srbima. Ne bi se oni brinuli za sudbinu Slovenaca, samo da ih stave pod svoju vlast, jer mi po njihovu mišljenju potpadamo pod 'srpsko carstvo'. Hrvati su posve drukčiji. Oni su već bili spremni prihvatiti naziv Iliri da bi olakšali udruživanje Slovenaca i Srba; neće zahtijevati nikakve povlastice, priznaju nas kao potpuno ravnopravnu braću." ${ }^{39}$ Glorifikacija ideje o južnoslavenskom udruživanju oko Hrvata prisutna je dakle barem u jednom povijesnom periodu na oba slovenska politička pola, a integracija oko Srbije nije se doživljavala kao ideja jugoslavenstva, nego prije svega kao opasnost od širenja Srbije.

\footnotetext{
37 Janko Prunk, Cirila Toplak, Marjeta Hočevar, Parlamentarna izkušnja Slovencev 1848-2004 (Ljubljana: Fakulteta za družbene vede, 2006), 60-61.

38 Edinost, 17. 8. 1887., 1.

39 Edinost, 17. 8. 1887., 1-2.
} 
Iz slovenske je perspektive dugo očekivana aneksija BiH shvaćena kao prilika za povećanje broja Južnih Slavena u Monarhiji i posljedično jačanje njihova političkoga položaja, čime bi treća jedinica trebala postati neizbježna. Na sastanku austrijske i ugarske parlamentarne delegacije 27. listopada 1908. vođa SLS-a Janez Evangelist Krek pozdravio je „prvi korak k ujedinjenju svih Južnih Slavena naše Monarhije u neovisnu državu pod žezlom dinastije Habsburg", ${ }^{40}$ a Janez Šusteršič konstatirao je: „... nadam se da će doći vrijeme kada će ne samo Bugari nego i Srbi na Balkanskom poluotoku, koji su nam još srodniji, shvatiti da bi najbolje jamstvo za slobodan razvoj Jugoslavena na Balkanu bila balkanska federacija pod vodstvom naše Monarhije." Ujedno se jasno opredijelio i glede budućnosti $\mathrm{BiH}$, koja se po njegovu mišljenju trebala pripojiti susjednim hrvatskim zemljama. ${ }^{41} \mathrm{U}$ to je vrijeme slično bilo i među slovenskim liberalima. O pripadnosti $\mathrm{BiH}$ Hrvatskoj pisali su i slovenski liberali iz Gorice ${ }^{42}$ i oni iz Trsta ${ }^{43}$ Međutim, primorski Slovenci ubrzo su shvatili da trijalizam neće biti lako ostvariti: „Lijepa je to ideja, no ovisi o previše različitih čimbenika. Bečka vlada vrlo vjerojatno na taj program neće pristati prije nego mađarski šovinizam. Ali onda imaju važnu riječ i Česi, jer njihovo državno pravo ima još veću povijesnu utemeljenost nego hrvatsko. Protiv ostvarenja češkoga prava nastupaju pak svi Nijemci i već dva milijuna Nijemaca u Češkoj faktor je s kojim moraju računati svi Slaveni. Nijemci u Češkoj nikad Česima neće dopustiti ostvarenje državnoga prava bez vlastite autonomije." ${ }^{\prime 4}$ Slovenski su liberali u tom kontekstu pokušali predložiti teritorijalnu podjelu koja bi zadovoljila sve strane. Nacrt Gregora Žerjava polazio je od ideje stvaranja posebnoga entiteta unutar Monarhije koji bi činile tri pokrajine, a svaka bi imala kraljeva predstavnika i pokrajinski sabor. ${ }^{45}$ Njegov se plan može opisati kao prijelazna faza u razvoju jugoslavenske ideje na liberalnom slovenskom polu. U tom su se periodu unutar NNS-a naime formirali prijedlozi koji su kombinirali povijesne i prirodno-pravne institute. U konkretnom je slučaju taj plan predviđao nužnost srpske jedinice unutar južnoslavenskoga entiteta. On doduše nije precizno definirao teritorijalnu podjelu, no iz opisa se može iščitati da je bio sklon ideji teritorijalnoga diskontinuiteta srpskoga dijela jer Vojvodina i veći dio $\mathrm{BiH}$, koje je Žerjav pripisivao Srbima, ne bi imale teritorijalni kontakt.

Zbog snažnoga suprotstavljanja različitih političkih grupacija vlast je odgodila konačnu odluku o pravnom statusu $\mathrm{BiH}$. U procesu pregovora o budućnosti anektiranih područja $u$ javnom se prostoru pojavila i alternativna opcija treće

\footnotetext{
40 Janko Prunk, Slovenski narodni programi: narodni programi v slovenski politični misli od 1848 do 1945 (Ljubljana: Društvo, 1986), 27.

${ }^{41}$ Rahten, Slovenska ljudska stranka v Dunajskem parlamentu, 81-83.

${ }^{42}$ Soča, 10. 10. 1908., 1.

${ }^{43}$ Edinost, 17. 12. 1908., 3-4.

44 Edinost, 23. 1. 1909., 2.

45 Prunk, Slovenski narodni programi, 25-27.
} 
upravne jedinice koja bi bila nešto manja nego što je isprva zamišljeno. Time se pokušavalo namiriti onaj dio Austrijanaca koji se zalagao za neposredan pristup Jadranu i, dakako, Talijane koji nisu željeli ući u državnu jedinicu sa središtem u Zagrebu i sa slavenskom većinom. Sa slovenskoga je stajališta član SLS-a Ivan Šusteršič 16. siječnja 1909. u središnjem parlamentu objasnio razliku između većega i manjega trijalizma: „... uži trijalizam (...) ograničen je na Hrvatsku, Slavoniju, Dalmaciju, Bosnu i Hercegovinu. Ako bi se trijalizam proveo na ovaj način, onda nam ništa ne bi koristilo, naprotiv, tada bi on bio na našu štetu jer bi se opet jedan dio Južnih Slavena, koji nas sada jača i podržava u Austriji, otuđio, otrgnuo!" ${ }^{\prime 6}$ Slovenski konzervativci očito su se pribojavali osnivanja treće jedinice bez Slovenaca. Na taj bi se način institucionalno potpuno odvojili od ostalih Južnih Slavena, što Slovencima, s obzirom na njihov zemljopisni položaj i okruženost većim narodima, nije baš nudilo privlačnu budućnost.

Uzimanje u obzir trijalizma bez Slovenaca ili samo s jednim njihovim dijelom najteže je bilo prihvatiti primorskim Slovencima. Posljedično su se upravo u njihovim tiskovinama počeli pojavljivati i članci koji su kritički nastupali prema takvu obliku federacije: „Nije li opravdan strah da se u slučaju trijalizma s tri vlade, tri parlamenta i tri izaslanstva broj spornih pitanja neće smanjiti, nego povećati i još više zakomplicirati?!"’7 Smatrajući da hrvatsko državno pravo nije koncept dovoljno širok da obuhvati sva slovenska područja, u takvim se izražavanjima sumnje prema trijalističkim planovima na udaru našao i taj institut: „Ostavimo takozvana povijesna prava i prašnjave pergamente. ... iz povijesnoga se prava može zaključiti sve i svašta. Ne na prašnjavim pergamentima, nego na životu, ne na povijesnom, nego na narodnom pravu moramo temeljiti naše zahtjeve." ${ }^{\prime 48}$ Takvi su istupi bili posljedica činjenice da je temeljni dokument kojim se dokazivala nadležnost hrvatskoga povijesnoga državnog prava na slovenskim teritorijima bila Hrvatska pragmatička sankcija iz 1712. ${ }^{49}$ kojom su Hrvati priznali vladavinu Habsburgovaca i ako dinastija ostane bez muških potomaka, no pritom su priznanje ograničili na onu kraljicu „... koja će imati ne samo Austriju, nego i pokrajine Štajersku, Korušku i Kranjsku, a stolovat će u netom spomenutoj Austriji.... ${ }^{50}$ Ali taj dokument nijednom riječju nije spominjao Goricu, Trst i Istru, pa su primorski liberalni Slovenci u temeljenju treće jedinice na hrvatskom državnom pravu vidjeli opasnost ostanka izvan te državne jedinice.

\footnotetext{
46 Rahten, Slovenska ljudska stranka $v$ Dunajskem parlamentu, 83-84.

47 Edinost, 24. 12. 1908., 1.

48 Edinost, 27. 12. 1908., 1.

49 O strateškim i taktičkim uzrocima nastanka Hrvatske pragmatičke sankcije vidi: Ivana Jukić, „Why Was the Habsburg Princess Granted the Right to Rule the Kingdom of Croatia in 1712?”, Povijesni prilozi 37 (2018), br. 54: 219-236.

50 Ivana Jukić, „Vladavina žena na Bečkom dvoru 1711./1712. i Hrvatska pragmatička sankcija”, Povijesni prilozi 25 (2006), br. 30: 120.
} 
Liberalni bi se dio primorskih Slovenaca vrlo vjerojatno zadovoljio prijedlogom Henrika Hanaua iz rujna 1909., prema kojem bi federalnu ilirsku jedinicu tvorile Hrvatska, Slavonija, Dalmacija, BiH, Istra s Trstom, Gorica, Kranjska, Donja Koruška i Donja Štajerska. Ugarski dio države činile bi Mađarska, Transilvanija, Galicija i Bukovina, a ostale pokrajine pripale bi njemačkoj, odnosno austrijskoj federalnoj jedinici. U Koruškoj i Štajerskoj granica bi bila Drava, stoga Maribor, Villach i Klagenfurt ne bi bili dio nove federalne jedinice. Zapadna granica išla bi između Tarvisija i Spodnjega Loga, s tim da bi potonji bio u ilirskom, a prvi u njemačkom dijelu. ${ }^{51}$ Ipak, i prema takvu su planu tršćanski liberalni Slovenci bili vrlo skeptični: „Da nam se ponudi trijalizam, mi bismo ga, naravno, morali objeručke prihvatiti. No ne smijemo zaboraviti da bi istovremeno s rješavanjem jugoslavenskoga pitanja i Česi zahtijevali ostvarenje svojega državnog prava ... Vjerojatno bi i Poljaci zahtijevali jednak tretman ... a Mađari sigurno nikada ne bi pristali na to." ${ }^{52} \mathrm{U}$ istom članku Edinost predlaže rješavanje mađarskoga problema i silom ako bude potrebno te nakon toga formiranje federalističke Austrije koja bi stupila u državnu zajednicu s Crnom Gorom, Srbijom, Bugarskom i Rumunjskom. Tršćanski Slovenci okupljeni oko Edinosti zalagali su se dakle za mnogo revolucionarniji koncept reorganizacije države, čija je osnova bilo stvaranje nacionalnih država na temelju narodnoga prirodnog, a ne povijesnog prava. To su slovenski liberali često predstavljali kao jedini način sprečavanja prepuštanja Talijanima i Nijemcima onih teritorija koje su smatrali slovenskim. ${ }^{53}$

\section{Razlike u strategijama slovenskih liberala i konzervativaca}

Strahovi Slovenaca uglavnom su bili opravdani jer su se u pitanju unutarnje reorganizacije na austrougarskoj političkoj pozornici na račun nacionalne komponente često zanemarivale sve druge ideološke sastavnice političkih programa. Zahtjeve njemačkih liberala za pristup Austrije Jadranskome moru podržali su primjerice i njemački kršćanski socijalisti, kojima su geopolitički prioriteti Nijemaca ipak bili važniji od ideološkoga saveza sa slovenskim socijalistima. To se jasno moglo iščitati iz govora kršćanskoga socijalista dr. Miklasa u lipnju 1909. godine: „Ako se trijalizam i ostvari, to ni na koji način ne bi trebalo značiti da se velikohrvatskoj državi dodaju i Kranjska, Primorje, južna Štajerska i tako dalje. Posljedica toga bilo bi zatvaranje pristupa moru istinskim nosiocima državne misli na kojima počiva snaga Carstva, a to su alpske i sudetske zemlje." ${ }^{54}$ Formiranjem njemačkoga bloka, koji se zauzimao za to da veći dio Primorja ostane u

\footnotetext{
${ }^{51}$ Edinost, 9. 9. 1909., 2.

52 Edinost, 28. 12. 1908., 1.

53 Edinost, 23. 1. 1909., 2.

${ }^{54}$ Janko Pleterski, „Trializem pri Slovencih in jugoslovansko zedinjenje”, Zgodovinski časopis 22 (1968), br. 1: 171; Prunk, Toplak, Hočevar, Parlamentarna izkušnja Slovencev, 62.
} 
austrijskom dijelu Carstva, započela je diplomatska borba slovenskih poslanika unutar i izvan središnjega parlamenta. Sve su oči bile uperene u najutjecajnijega slovenskoga političkog predstavnika u to vrijeme, Ivana Šusteršiča. Njegova strategija pripajanja slovenskoga teritorija trećoj jedinici sastojala se od dva dijela. Najprije je pokušao stvoriti južnoslavenski blok, odnosno udruženje južnoslavenskih političkih stranaka koje bi surađivale u bečkom parlamentu. U siječnju 1909. nakon brojnih pregovora formiran je Slavenski centrum oko SLS-a, a zatim je ustanovljena još šira grupacija nazvana Slavenska unija. Snaga te političke koalicije bila je vrlo važna za Slovence jer je sa 125 zastupnika postala najveća grupacija u središnjem parlamentu. Mjesto predsjedajućega u Slavenskoj uniji još je povećalo Šusteršičevu moć i njegov utjecaj na najvažnije političke odluke u Monarhiji. Među ostalim, izabran je i za predsjednika odsjeka za aneksiju BiH, što mu je dalo priliku da aktivno provodi politiku trijalizma. Drugi dio njegove političke strategije sastojao se od očekivanja da će već staroga Franju Josipa na mjestu cara uskoro zamijeniti Franjo Ferdinand. Šusteršič je upravo zbog toga intenzivno lobirao kod prijestolonasljednika, kojega je više puta pokušao upozoriti na to da će Habsburgovci imati velike koristi od uspostave treće jedinice, prije svega radi protuteže najopasnijim neprijateljima dinastije: mađarskom šovinizmu, talijanskom i srpskom iredentizmu. ${ }^{55}$ Pritom je dakako izbjegavao spomenuti razdvajajuću funkciju treće jedinice između njemačkoga i slovenskoga teritorija te je stavljao fokus rasprave na smanjenje mađarske, talijanske i srpske moći. Znajući za simpatije Franje Ferdinanda prema Hrvatima, naglašavao je hrvatsko državno pravo kao temeljni element trijalističke ideje. Potvrdio je to i u javnom govoru u Ljubljani 1909. godine: „Hrvati i mi smo ustvari braća, mi smo jedan narod ... mi Slovenci osjećamo (se) kao ogranak hrvatske nacije, hrvatskoga tijela. ... Naš je ideal, a to znate svi, da u tijesnoj vezi s Hrvatima projektiramo veliku jugoslavensku državu od Soče do Drine od Mure i Drave do Jadranskoga mora pod moćnim žezlom vladajuće obitelji Habsburg." 56 Priznavanje hrvatskoga povijesnoga državnog prava i uključivanje $\mathrm{BiH}$ te Slovenaca u okvir trijalizma unutar Habsburške Monarhije bilo je konstanta u Šusteršičevoj strategiji rješavanja južnoslavenskoga pitanja. Prije balkanskih ratova unutar SLS-a nitko se tome nije suprotstavljao. Prema Šusteršičevoj viziji, granica buduće države Južnih Slavena trebala je biti na rijeci Drini. Dugoročno bi mogla privući i Srbiju, ali za slovenske konzervativce to bi bilo moguće samo ako bi Srbi prihvatili katoličko vodstvo države. Kada su se na Balkanu već dogodile geopolitičke promjene, 4 . listopada 1912. Straža, časopis pod utjecajem Antona Korošca, istaknutoga člana SLS-a i njegova budućega vođe, objavila je članak o toj potencijalno široj Jugoslaviji. ${ }^{57}$ No tisak pod utjecajem konzervativnoga SLS-a nikada u svojim objavama

\footnotetext{
55 Rahten, Slovenska ljudska stranka v Dunajskem parlamentu, 117.

56 Slovenec (Ljubljana), 19. 7. 1909., 1.

57 Rahten, Slovenska ljudska stranka v Dunajskem parlamentu, 125.
} 
nije govorio o Trstu, Gorici i Istri. Usredotočio se samo na slovenske zemlje koje je spominjala Pragmatička sankcija, što je uzrokovalo još veći jaz između konzervativnoga i liberalnoga političkog pola.

Percepcija da je SLS voljan ostaviti Trst i Goricu izvan južnoslavenske jedinice u zamjenu za austrijsku i talijansku potporu trijalizmu imala je snažan negativan učinak na primorske Slovence. Golemu su energiju stoga počeli ulagali u kritiku trijalizma u svojim medijima, što je posebice bilo primjetno kada je 1911. u Zagrebu objavljena brošura Put do trializma.$^{58}$ Tršćanski liberalni Slovenci nezadovoljstvo su izrazili i prilikom objave članka u hrvatskom časopisu Trializam, koji je u srpnju 1912. trećoj jedinici priključio Goricu i Rijeku, no ispustio Trst: „Tako dakle! Rijeka da, a Trst ne! Normalno, jer je Rijeka hrvatski grad pa se ne smije izgubiti! A Trst (...) može vrag odnijeti! ... Prste dalje, gospodo oko 'Trializma', od našega narodnog vlasništva, od našega tršćanskog teritorija!" ${ }^{59}$ Odbijanje trijalizma bez Trsta kod primorskih je Slovenaca urodilo stvaranjem alternativnih koncepata koji bi bili prihvatljivi prije svega za sve Slovence, a potom i sve slavenske političke stranke u Habsburškoj Monarhiji. Strategija dobivanja češke, slovačke i poljske potpore zasnivala se na federalističkome modelu državne organizacije u kojoj bi svaki narod dobio vlastitu federalnu jedinicu na temelju prirodnoga prava. Dana 20. lipnja 1912. slovenski liberalni političar i tršćanski vijećnik Otokar Rybář pozvao je na ujedinjenje Južnih Slavena u Monarhiji i federalizaciju države ${ }^{60} s$ najmanje četiri federalne jedinice. Takav su stav slovenski liberali branili praktički do kraja Prvoga svjetskog rata. ${ }^{61}$

Promjena odnosa prema trijalizmu među primorskim liberalnim Slovencima prenijela se i na njihov odnos prema katoličanstvu i pravoslavlju te posredno i na njihovo razumijevanje habsburških Srba. Slovenski su liberali naime najprije kritizirali srpsku autonomističku politiku u $\mathrm{BiH}$, što se odražavalo u objavama Edinosti i Soče. ${ }^{62}$ Unatoč početnome stavu, slovenski liberalni tisak ipak je s vremenom pokazivao sve više razumijevanja za srpske težnje te je i sam kritizirao ideju dominacije katolika u trećoj jedinici federalne Monarhije: „Ne možemo se onda nimalo čuditi Srbima ako izjavljuju da žele autonomiju Bosne te se izmiču koncentraciji katolika, jer znadu da bi time stavili svoje glave pod sjekire katoličkih dželata." ${ }^{63}$ Slične su se kritike redale sve do balkanskih ratova ${ }^{64}$ čime su, pored zastupanja šire federalističke ideje radi dobivanja potpore Čeha i Poljaka,

\footnotetext{
${ }^{58}$ Edinost, 3. 9. 1911., 1.

59 Edinost, 25. 7. 1912., 1.

60 Edinost, 23. 6. 1912., 1.

${ }^{61}$ Edinost, 5. 9. 1917., 1.

${ }^{62}$ Edinost, 25. 2. 1912., 1; Edinost, 27. 2. 1912., 1-2.

${ }^{63}$ Soča, 9. 3. 1911., 1.

${ }^{64}$ Soča, 16. 4. 1912., 1-2.
} 
slovenski liberali pokušali pronaći saveznika i među Južnim Slavenima. Pritom su ih geografski periferan položaj i liberalno-panslavenska orijentacija sve više gurali prema široj viziji jugoslavenstva, što je u ono vrijeme značilo i u zagrljaj promotora srpske vizije južnoslavenske države. Objave u Soči i Edinosti jasno pokazuju da je jezgra južnoslavenske ideologije liberalnih Slovenaca bila bitno drugačija od one slovenskih katoličkih konzervativaca. Za potonje je ključ južnoslavenske zajednice bio u slovensko-hrvatskom jedinstvu, koje se temeljilo na pripadnosti zapadnoj kulturi i rimokatoličkoj religiji, a liberali su u prvi plan stavljali slavenstvo kao temeljni element južnoslavenske političke integracije.

\section{Srpska reakcija na aneksiju Bosne i Hercegovine}

Aneksija BiH za Srbiju je praktički značila objavu rata. Brojne su tiskovine radikalizirale javno mišljenje i potpirivale objavu rata Habsburškoj Monarhiji. ${ }^{65}$ Vlast Kraljevine Srbije ipak je postupala nešto opreznije te se čuvala radikalnih istupa jer je tada odnos snaga još bio nepovoljan za Srbiju. ${ }^{66}$ Habsburška Monarhija bila je u vojnom smislu prejak protivnik, a Srbija nije mogla računati ni na znatniju pomoć zapadnih sila ili iscrpljene Rusije. Ipak, aneksija je označila razdoblje još intenzivnijega djelovanja srpske diplomacije. Dio je radio na dobivanju neke vrste kompenzacije u obliku srpskoga izlaza na more i priključenja barem istočnoga dijela $\mathrm{BiH},{ }^{67}$ a regent Aleksandar predstavio je u Sankt Peterburgu ruskome caru ideju šire Jugoslavije koja bi pored Srbije uključivala i $\mathrm{BiH}$, hrvatske teritorije, Crnu Goru, Vojvodinu, Kosovo i makedonska područja.$^{68}$ Odgovor na aneksiju nije bio ograničen samo na traženje potpore velikih sila, nego se pojačala i srpska politička aktivnost u samoj Habsburškoj Monarhiji. Zaživjela su stara i nova politička društva, u Dubrovniku je glasilo Dubrovnik prosvjedovalo protiv aneksije i pozivalo na jedinstvo Srba na okupiranim područjima. ${ }^{69} \mathrm{U} \mathrm{BiH}$ se isticala Mlada Bosna, sastavljena uglavnom od radikalnoga srpskog stanovništva, sa zahtjevima o „oslobađanju” i pripajanju jugoslavenskoj (srpskoj) matici. Srpski odnos prema BiH odražavao je rad beogradskoga profesora Jovana Cvijića Aneksija Bosne i Hercegovine i srpsko pitanje u kojem su Hrvati katolici opisani kao element pod kontrolom austrijske antisrpske politike. Prema Cvijiću, Srbi su bili jedini legitimni predstavnici Jugoslavije zbog svoje brojnosti i središnjega geografskog položaja među Južnim Slavenima. U tom su kontekstu sukobi između Hrvata i Srba definirani kao odraz jugoslavensko-njemačkoga sukoba, a proces

\footnotetext{
65 Bakić, Ideologije jugoslovenstva, 118.

${ }^{66}$ Stanković, Nikola Pašić, 20.

67 Pilar, Južnoslavensko pitanje, 357-358.

68 Bogdan Sajovic, Od male Srbije do velike Jugoslavije (Ljubljana: Založba Karantanija, 2006), 20-23.

${ }^{69}$ Pero Depolo, „Političke struje u Dubrovniku i aneksija Bosne i Hercegovine (I. dio)”, Anali Dubrovnik 37 (1999): 327.
} 
homogenizacije jugoslavenstva izjednačen je sa širenjem srpske svijesti na ostale Južne Slavene. Trijalizam iz te perspektive nije bio ništa drugo nego institut anti(jugo)slavenske politike s ciljem germanskoga osvajanja Balkana. ${ }^{70}$ Aneksija je dakle ubrzala homogenizaciju srpskih jugoslavenskih koncepata, trijalizam je stekao status antisrpske ideje, a Srbija je u srpskom tisku ostala jedini legitimni stup jugoslavenstva. Stav Srbije prelijevao se u političke aktivnosti habsburških Srba, koji su započeli kampanju protiv hrvatsko-austrijske ideje trijalizma, istovremeno prihvaćajući dualizam sve dok to nije impliciralo priključenje $\mathrm{BiH}$ Ugarskoj. ${ }^{71}$ Unatoč relativno nepovoljnijem položaju, bosanskohercegovački Srbi uspješno su manevrirali i iskorištavali hrvatsko-mađarske sukobe te na kraju sve do Prvoga svjetskog rata uspjeli sačuvati status quo.

Radi jačanja svojega međunarodnog položaja Srbija se usmjerila na najslabiji subjekt, Osmansko Carstvo, za što je sklopila savez s Bugarskom, Grčkom i Crnom Gorom. Srpsko-bugarsko partnerstvo također je bilo bitno u pogledu rješavanja južnoslavenskoga pitanja, što je potvrdio srpski ministar vanjskih poslova Milovan Milovanović kada je pokušao opisati srpske poglede na situaciju na Balkanu svojem bugarskom kolegi: „Za nas je u svemu tome još jedan važan aspekt koji nas potiče na sporazum s Bugarskom. Sve dok nismo povezani s vama, naš će utjecaj na Hrvate i Slovence biti beznačajan. Unatoč različitoj vjeri, ti ljudi u velikoj mjeri imaju sličnu kulturu kao mi. No oni ne vide Srbiju kao centar koji bi ih mogao privući. Posve će drugačije biti ako mi ostvarimo snažan blok. Onda će svi pravoslavni i katolički Srbi, Hrvati i Slovenci u susjednoj Monarhiji početi neizbježno gravitirati nama." ${ }^{72}$ Slično je i srpski veleposlanik u Bugarskoj Miroslav Spalajković izrazio bojazan francuskom veleposlaniku da bi Franjo Ferdinand, nakon što zauzme habsburško prijestolje, mogao osnovati treću jedinicu u Monarhiji, koja bi onda mogla živjeti i bez Srbije ili čak privući Srbe i Crnogorce u okvir Habsburške Monarhije. ${ }^{73}$

\section{Reakcije Hrvata i Slovenaca na balkanske ratove}

Uspjesi Srbije u balkanskim ratovima budili su miješane osjećaje i među Slovencima i među Hrvatima. Jedan je dio slavio pobjede srpske vojske, a neki su se čak i pridružili srpskim ratnim kampanjama. U pojedinim gradovima i selima, prije svega u područjima sa znatnijim udjelom srpskoga stanovništva, zavijorile su se

\footnotetext{
70 Pilar, Južnoslavensko pitanje, 365-366.

71 Edinost, 12. 4. 1911., 1-2.

72 Richard C. Hall, The Balkan Wars 1912-1913. Prelude to the First World War (London; New York: Routledge, 2000), 10.
}

73 Rahten, Slovenska ljudska stranka v Dunajskem parlamentu, 126-128. 
srpske zastave unatoč austrijskoj upravi. ${ }^{74}$ Koalicija je pokušala zajahati taj val protuosmanskih pobjeda te steći popularnost povezujući rat na Balkanu s pobjedom jugoslavenstva i izjednačujući srpsku borbu s vlastitim političkim ciljevima. Tome je pridonijela i opća politička i ekonomska situacija u Hrvatskoj, Slavoniji ${ }^{75}$ i Dalmaciji, gdje se nezadovoljstvo stanovništva kanaliziralo u potragu za političkim alternativama. Još prije balkanskih ratova dio mladeži Starčevićeve stranke prava, čija je matica težila suradnji s Koalicijom, djelomično je odstupio od koncepta hrvatskoga državnog prava neočekivano prešavši na pozicije jugoslavenskoga unitarizma sa Srbijom u centralnoj poziciji. ${ }^{76}$ Prema njihovu tumačenju, spor između Hrvata i Srba odnosio se samo na ime, što je prema istom tumačenju bilo marginalno, a pridružio im se i dio studenata, i socijalista i liberala, te su težili suradnji s jugoslavenskim nacionalističkim organizacijama. Kao pristaša Koalicije, svojim prosrpskim pogledima među dalmatinskim Hrvatima isticao se Ante Trumbić, stječući tako srpske simpatije, iako je prema nekim dokumentima i sam bio svjestan opasnosti koju predstavlja država Južnih Slavena bez Slovenaca. ${ }^{77} \mathrm{Na}$ drugoj je strani, čak i nakon smrti Josipa Franka, Čista stranka prava nastavila s proaustrijskom politikom, koja je uključivala ideju velike hrvatske države unutar Monarhije. Treću je stranu u hrvatskoj politici zastupao Stjepan Radić, koji je odbacio ideju o ujedinjenju sa Srbijom, posebno nakon početka drugoga kruga balkanskih ratova, što je prema Radiću bilo ništa drugo nego „nebratsko klanje" 78 te ujedno manifestacija ludosti i pokvarenosti Srbije, koja je inscenirala taj rat. ${ }^{79}$ Stanje u BiH bilo je složenije zbog odnosa među tri etničke skupine. Srpske ratne pobjede dočekane su s oduševljenjem samo među srpskim pučanstvom, a većina Hrvata i Muslimana sa strahom je gledala poraze Osmanlija. ${ }^{80}$

Balkanski ratovi unijeli su iskru razdora u SLS. Konzervativni časopis Slovenec u početku je izražavao simpatije prema slavensko-grčkoj koaliciji i njezinu napredovanju protiv Turaka, a u nekoliko slučajeva objave u Slovencu čak su i slavile srpsku i crnogorsku vojsku. To je uglavnom bio odraz Krekovih stavova, kojima se suprotstavljao Šusteršič, pokušavajući iz slovenskoga političkog spektra ukloniti sve što je štetilo slovenskim odnosima s Bečom. U kontekstu dokazivanja svoje lojalnosti caru 20. listopada 1912. organizirao je skup na kojem je SLS kao svoju političku

\footnotetext{
74 Lampe, Yugoslavia as history, 95.

75 Mislav Gabelica, „Sporazum između Stranke prava i Hrvatsko-srpske koalicije (1912. -1913.)”, Časopis za suvremenu povijest 44 (2012), br. 3: 742.

76 Mislav Gabelica, „Pravaška mladež na hrvatskom Sveučilištu uoči Prvog svjetskog rata”, Društvena istraživanja 20 (2011), br. 4: 1155.

77 Slovence je vidio kao protutežu srpskoj dominaciji, što je i priznao u pismu Franu Supilu 1914. godine (Prunk, Toplak, Hočevar, Parlamentarna izkušnja Slovencev, 67-68).

78 Bogdan Krizman, „Stjepan Radić i Hrvatska pučka seljačka stranka u prvom svjetskom ratu”, Časopis za suvremenu povijest 2 (1970), br. 2: 99.

79 Rumjana Božilova, „Knjiga Stjepana Radića o Bugarima”, Povijesni prilozi 14 (1995), br. 14: 261.

80 Lampe, Yugoslavia as history, 99.
} 
platformu potvrdio program hrvatskih pravaša i težnju za stvaranjem katoličke južnoslavenske jedinice unutar Monarhije. Donesena je rezolucija u kojoj se navodi da Slovenci i Hrvati tvore jednu nacionalnu cjelinu te žele djelovati u duhu i prema programu Stranke prava za jedinstvo, prava i razvoj hrvatsko-slovenskoga naroda unutar Habsburške Monarhije. Doduše, ni Krek se nije protivio stavu o jednoj hrvatsko-slovenskoj političkoj naciji. Dapače, svojim je studentima i dalje govorio da su Slovenci ustvari planinski Hrvati. Aleš Ušeničnik, jedan od vodećih ideologa SLS-a, također je tvrdio da je za Slovence kroatizacija mnogo bolja od germanizacije. Naime, Slovenci bi u tom slučaju od Hrvata trebali preuzeti samo jezik, a prema njegovu mišljenju s drugih kulturnih aspekata Hrvatima su mogli dati mnogo više, što bi posljedično Hrvate u većoj mjeri napravilo Slovencima nego obrnuto. ${ }^{81} \mathrm{U}$ odnosu prema Srbima Krek je bio spreman na ustupke u pogledu vjerske autonomije, no samo uz uvjet da Srbi priznaju hrvatsko državno pravo. S druge strane Šusteršič Srbiji nije uskraćivao njezino pravo na pristup moru te je donekle i sam kritizirao neaktivnost austrougarske politike. ${ }^{82}$ Očigledno propadanje Osmanskoga Carstva Šusteršiča je nagnalo na prijedlog pregovora sa Srbijom. Prema njegovim riječima, s mogućim partnerstvom i podrškom Srbiji u osvajanju albanskoga teritorija $\mathrm{Au}$ stro-Ugarska bi mogla osigurati stabilnost na svojoj jugoistočnoj granici te priključiti BiH hrvatsko-slovenskoj jedinici. Velike geopolitičke razlike između Kreka i Šusteršiča dakle nije bilo. Nastavila se politika zahtijevanja zajedničke domovine za jedinstveni hrvatsko-slovenski narod u habsburškom okviru, ${ }^{83}$ što je potvrdio i sam Krek neposredno prije Sarajevskoga atentata i početka Prvoga svjetskog rata: „Riješite jugoslavensko pitanje tako da katoličke Hrvate i Slovence stavite zajedno unutar austrijskoga carstva i tada će zemlja biti toliko jaka da ćete uvijek imati slobodne morske putove." ${ }^{4}$ I Šusteršič i Krek nade su polagali u Franju Ferdinanda premda je i on koketirao s planovima koji nisu bili sasvim u skladu sa slovenskim željama.

Uspjeh protuosmanske balkanske koalicije nije podijelio slovenske liberale. $\mathrm{Za}$ njih je Prvi balkanski rat bio uvod u ujedinjenje Slavena na jugoistoku Europe. ${ }^{85}$ $\mathrm{U}$ to su vrijeme slovenski liberalni časopisi prikazivali Srbiju kao ideal borbe za jugoslavensku slobodu, a bečka antisrpska politika izjednačavana je $s$ antislavenstvom. Euforija potaknuta prvim krugom balkanskih ratova dovela je do strahovitoga porasta negativnih objava o Nijemcima i Talijanima, a i do radikalnih zahtjeva za federalizaciju Habsburške Monarhije. ${ }^{86}$ Euforija se mogla osjetiti i u

\footnotetext{
81 Jurij Perovšek, „Ušeničnik in jugoslovanstvo”, u: Aleš Ušeničnik: čas in ideje, 1868-1952. Zbornik razprav s simpozija SAZU ob 50. obletnici smrti, ur. Matija Ogrin i Janez Juhant (Celje: Mohorjeva družba, 2004), 102.

82 Slovenec, 8. 11. 1912., 1.

83 Slovenec, 16.3. 1914., 1.

84 Slovenec, 23. 5. 1914., 1-2.

85 Edinost, 23. 3. 1913., 1.

${ }^{86}$ Soča $1.2 .1913 ., 1-2$.
} 
Trstu i u Gorici. Slovenski liberali iz sjevernoga Austrijskog primorja također su odbacivali trijalizam i zahtijevali federaciju na Balkanu, dok su istovremeno pozivali na povezivanje habsburških Južnih Slavena s drugim Slavenima na Balkanu. ${ }^{87}$ Balkanska federacija i Austrija prema tim željama trebale su dakle stvoriti neku vrstu konfederacije. No pritom nije posve jasno koji bi bio opseg takve balkanske federacije. Prema ovom bismo pisanju ipak mogli zaključiti da su slovenski liberali iz Gorice bar privremeno predviđali svoj ostanak u Austriji.

Nakon drugoga kruga balkanskih ratova euforiju slovenskih liberala zamijenila je frustracija sukobima među Južnim Slavenima: „Balkanski će Slaveni progledati tek kada Stara Srbija i Makedonija dođu pod tuđu šaku; ... Tada će braća i susjedi pružiti ruku jedan drugome, no bit će teško razbiti lance, otrgnuti pijavice, i teško ili nemoguće srušiti most koji su Nijemci izgradili preko balkanskih zemalja, preko duša i svetinja balkanskih naroda do Soluna i Orijenta." ${ }^{88} \mathrm{Od}$ toga trenutka panslavenska struja slovenskih naprednjaka suzila je pojam ,jugoslavenske nacije" na Slovence, Hrvate i Srbe, bez Bugara. Slovenski panslavisti i zagovornici najširega jugoslavenskoga koncepta odstupili su od svojih ideala i pomirili se s političkom stvarnošću. Čini se da pritom tršćanski slovenski liberali nisu bili svjesni da udaljavanje geopolitičkoga središta buduće jugoslavenske države povećava opasnost od periferizacije zapadnih slovenskih područja i smanjuje njihovu vrijednost u očima odlučujućih političkih aktera. Objektivniji su u tom pogledu bili u Gorici jer je gorička Soča nešto više od mjesec dana prije Sarajevskoga atentata objavila sljedeći komentar političke situacije: „Manifestacije u Italiji pokazuju najnovije tendencije talijanske politike. Ta je politika usmjerena u prvom redu protiv nas, Slovenaca i Hrvata. ... Italija se danas sprema na rat $\mathrm{i}$ zauzimanje cijele obale od izvora Soče do Boke kotorske. ... I što je još zanimljivije, pritom računa na podršku Srbije." ${ }^{89}$ Pomiješane reakcije slovenskih liberala, posebice onih iz Austrijskoga primorja, odražavaju njihovo lutanje u potrazi za rješenjem u iznimno teškoj situaciji za taj dio slovenskoga narodnoga korpusa. Njihovi politički pokušaji nisu polučili znatniji rezultat prije Prvoga svjetskog rata. Nisu naime uspjeli dobiti veću potporu čak ni među Slovencima, što je posljedično marginaliziralo njihovu ulogu u širem južnoslavenskom kontekstu i na razini Habsburške Monarhije. Neuspjeh u realizaciji trijalizma na temeljima hrvatskoga povijesnog prava bio je doduše u skladu s njihovim zalaganjem nakon kristalizacije politike „novoga kursa” i pogotovo nakon balkanskih ratova. Unatoč tomu, za tu im se činjenicu ne može pripisati mnogo zasluga jer su njihovi postupci uglavnom ostajali na marginama političke scene, stoga razloge neuspjeha koncepta trijalizma treba tražiti u širem kontekstu međunarodnih odnosa.

\footnotetext{
87 Soča, 1. 2. 1913., 2 .

88 Soča, 10. 9. 1912., 1-2.

89 Soča, 16. 5. 1914., 1.
} 


\section{Zaključak}

Nefunkcionalnost dualističkoga uređenja države i promijenjena ravnoteža snaga na Balkanu bile su uzroci osmišljavanja reorganizacije Habsburške Monarhije koja bi Austriji omogućila lakše odlučivanje i učinkovitiju vanjsku politiku. Na unutarnjem planu glavna prepreka trijalističkoj ideji bila je mađarska politička elita, a najveći vanjski neprijatelj federalizacije Monarhije bila je Srbija. U vrijeme očitoga slabljenja Osmanskoga Carstva nazirala se opasnost jačanja srpske države, koja ne bi bila samo snažan konkurent na Balkanu nego i važan čimbenik privlačenja barem dijela habsburških Južnih Slavena, što bi makar posredno utjecalo i na češko razmišljanje o budućnosti izvan Austro-Ugarske. Za potonju je, pored potencijalnoga povezivanja balkanskih zemalja u antihabsburški blok, opasnost bila i talijanska aspiracija na Južni Tirol i sve snažnija Rusija, koja se željela ponovo angažirati u tom dijelu Europe..$^{90}$ Međutim, unatoč svijesti o posljedicama stvaranja velike srpske države, u Austriji nije postojao konsenzus o tome kako bi Habsburška Monarhija trebala biti uključena u rješavanje problema. Neki su predlagali preventivni rat, drugi su savjetovali vođenje pozitivne politike prema Srbiji te njezino dovođenje u stanje ekonomske ovisnosti. Franjo Josip nije bio sklon ratu, a Franjo Ferdinand bio je i protiv bilo kakva oblika aneksije Srbije. ${ }^{91}$ Rat je tada bio daleko od idealne opcije za Monarhiju, no istovremeno napori uloženi u federalizaciju Habsburške Monarhije nisu bili dovoljni da bi se prevladalo protivljenje mađarskih, talijanskih i pojedinih njemačkih političkih grupacija. Nedostajala je i koordinirana slavenska politika. Inzistiranje na posebnom hrvatsko-slovenskom statusu izoliralo je SLS i njihove hrvatske partnere u središnjoj političkoj instituciji Monarhije. Udarac trijalizmu bio je izostanak potpore Čeha, koji su strahovali da bi ih ostvarenje te zamisli ostavilo kao jedine Slavene u austrijskom dijelu Monarhije. Čak ni svi Slovenci i Hrvati nisu aktivno provodili politiku trijalizma. Jedan je dio odustao smatrajući ideju nerealnom, a primorski slovenski liberali bojali su se da bi mogli ostati izvan te jedinice. Posljedično su se počeli okretati alternativnim idejama, poput širega federalizma Habsburške Monarhije, pa čak i srpskoj verziji jugoslavenske države. Trijalizam je zapravo bio samo još jedno od brojnih bojnih polja u kontekstu sukoba različitih južnoslavenskih koncepcija. Ishod te borbe odredile su šire međunarodne okolnosti koje su zapečatile sudbinu Habsburške Monarhije, a uspostavom Kraljevine Srba, Hrvata i Slovenaca trijalizam je ostao tek bolna uspomena za njegove istinske sljedbenike.

\footnotetext{
90 Andrej Mitrović, Prodor na Balkan. Srbija u planovima Austro-Ugarske i Nemačke 1908-1918 (Beograd: Nolit, 1981), 100-101.

${ }_{91}$ Rahten, Slovenska ljudska stranka $v$ Dunajskem parlamentu, 126.
} 


\section{Objavljeni izvori i literatura}

Bakić, Jovo. Ideologije jugoslovenstva između srpskog i hrvatskog nacionalizma 1918-1941. Zrenjanin: Gradska narodna biblioteka „Žarko Zrenjanin”, 2004.

Banac, Ivo. Nacionalno pitanje u Jugoslaviji: porijeklo, povijest, politika. Zagreb: Globus, 1988.

Boban, Branka. „Mladi Stjepan Radić o Srbima u Hrvatskoj i odnosima Hrvata i Srba”. Radovi 28 (1995), br. 1: 128-137.

Božilova, Rumjana. „Knjiga Stjepana Radića o Bugarima”. Povijesni prilozi 14 (1995), br. 14: 259-277.

Bulić, Ivan. „Politika Hrvatsko-srpske koalicije uoči Prvoga svjetskog rata 1907. - 1913." Časopis za suvremenu povijest 44 (2012), br. 2: 415-453.

Depolo, Pero. „Političke struje u Dubrovniku i aneksija Bosne i Hercegovine (I. dio)". Anali Dubrovnik 37 (1999): 251-331.

Depolo, Pero. „Političke struje u Dubrovniku i aneksija Bosne i Hercegovine (II. dio)". Anali Dubrovnik 38 (2000): 243-303.

Edinost (Trst), 1887, 1905, 1908-1913, 1917.

Evans, Ifor L. „Economic Aspects of Dualism in Austria-Hungary”. The Slavonic and East European Review 6 (1928), br. 18: 529-542.

Gabelica, Mislav. „Političke prilike u Banskoj Hrvatskoj na početku Prvog svjetskog rata". Društvena istraživanja 23 (2014), br. 1: 177-197.

Gabelica, Mislav. „Pravaška mladež na hrvatskom Sveučilištu uoči Prvog svjetskog rata”. Društvena istraživanja 20 (2011), br. 4: 1139-1161.

Gabelica, Mislav. „Sporazum između Stranke prava i Hrvatsko-srpske koalicije (1912. - 1913.)". Časopis za suvremenu povijest 44 (2012), br. 3: 723-743.

Gabršček, Andrej. Goriški Slovenci - narodne, kulturne, politične in gospodarske črtice, knjiga 2: Od leta 1901 do 1924. Ljubljana, 1934.

Hall, Richard C. The Balkan Wars 1912-1913. Prelude to the First World War. London; New York: Routledge, 2000.

Ivašković, Igor. „Geopolitički zaokret liberalnih slovenskih krugova u Primorskoj pred Prvi svjetski rat”. Časopis za suvremenu povijest 52 (2020), br. 1: 193-217.

Ivašković, Igor. „The Implications of the New Course Strategy”. Politička misao: časopis za politologiju 56 (2020), br. 3-4: 218-238.

Jukić, Ivana. „Vladavina žena na Bečkom dvoru 1711./1712. i Hrvatska pragmatička sankcija”. Povijesni prilozi 25 (2006), br. 30: 103-127. 
Jukić, Ivana. „Why Was the Habsburg Princess Granted the Right to Rule the Kingdom of Croatia in 1712?” Povijesni prilozi 37 (2018), br. 54: 219-236.

Kalc, Aleksej. „Vidiki razvoja prebivalstva Goriške-Gradiške v 19. stoletju in do prve svetovne vojne". Acta Histriae 21 (2013), br. 4: 683-706.

Krizman, Bogdan. „Stjepan Radić i Hrvatska pučka seljačka stranka u prvom svjetskom ratu". Časopis za suvremenu povijest 2 (1970), br. 2: 99-165.

Lampe, John R. Yugoslavia as history. Twice there was a country. Second edition. Cambridge: Cambridge University Press, 2000.

Matković, Stjepan. Čista stranka prava 1895. - 1903. Zagreb: Hrvatski institut za povijest, 2001.

Matković, Stjepan. Premili Ivane: korespondencija Ivana Hribara s hrvatskom elitom. Zagreb: Hrvatski institut za povijest, 2016.

Mitrović, Andrej. Prodor na Balkan. Srbija u planovima Austro-Ugarske i Nemačke 1908-1918. Beograd: Nolit, 1981.

Perovšek, Jurij. „Ušeničnik in jugoslovanstvo”. U: Aleš Ušeničnik: čas in ideje, 1868-1952. Zbornik razprav s simpozija SAZU ob 50. obletnici smrti, uredili Matija Ogrin i Janez Juhant, 97-110. Celje: Mohorjeva družba, 2004.

Pilar, Ivo. Južnoslavensko pitanje. Prikaz cjelokupnog pitanja. Varaždin: Hrvatska demokratska stranka, Podružnica Varaždin, 1990.

Pirjevec, Jože. Trst je naš! Boj Slovencev za morje (1948-1954). Ljubljana: Nova revija, 2007.

Pleterski, Janko. „Trializem pri Slovencih in jugoslovansko zedinjenje”. Zgodovinski časopis 22 (1968), br. 1: 169-184.

Prunk, Janko. Slovenski narodni programi: narodni programi v slovenski politični misli od 1848 do 1945. Ljubljana: Društvo, 1986.

Prunk, Janko; Toplak, Cirila; Hočevar, Marjeta. Parlamentarna izkušnja Slovencev 1848-2004. Ljubljana: Fakulteta za družbene vede, 2006.

Rahten, Andrej. Slovenska ljudska stranka v Dunajskem parlamentu. Slovenska parlamentarna politika v Habsburški monarhiji 1897-1914. Celje: Cenesa, Založba Panevropa, 2001.

Sajovic, Bogdan. Od male Srbije do velike Jugoslavije. Ljubljana: Založba Karantanija, 2006.

Slovenec (Ljubljana), 1909, 1912, 1914.

Soča (Gorica), 1906, 1908-1914. 
„Spezialortsrepertorium für das österreichisch-illyrische Küstenland: bearbeitet auf Grund der Ergebnisse der Volkszählung vom 31. Dezember 1910 / herausgegeben von der K. k. statistischen Zentralkommision". Spezialortsrepertorium der österreichisch Länder 7. Beč: K. k. Hof- und Staatsdruckerei, 1918.

Stanković, Đorđe. Nikola Pašić, saveznici i stvaranje Jugoslavije. Beograd: Nolit, 1984.

Wank, Solomon. „Aehrenthal's Programme for the Constitutional Transformation of the Habsburg Monarchy: Three Secret 'Mémoires"'. The Slavonic and East European Review 41 (1963), br. 97: 513-536. 
Igor Ivašković*

\section{The Trialist Reform of Austro-Hungary in Liberal Slovene Newspapers from Trieste and Gorizia}

\section{Summary}

Based on the liberal Slovenian newspapers from Trieste (Edinost) and Gorizia (Soča), the paper focuses on the idea of introducing the third state unit in the Habsburg Monarchy before the First World War. The author first presents the broader context in which the concept was formed and then analyses the comments of two newspapers on the reactions of various political groups, their ambitions, and the national tensions that arose in the context of discussing the proposed reform. The author argues that the trialist concept was, foremost, an Austrian attempt to federalize the Habsburg Monarchy in order to reduce the strength of Hungary. At the beginning of the $20^{\text {th }}$ century, the majority of Slovenes and Croats, including the Slovene liberals from Trieste and Gorizia, supported this idea because it implied their political emancipation. On the other hand, Hungarians, Italians, German nationalists, and Serbs saw this concept as a threat to their own national interests. In the further development of the trialist concept, due to Austria's ambitions to satisfy the Italians, Trieste and Gorizia were excluded from the imagined third unit, which led to tensions between the Slovenian liberals and conservatives, and in the Croatian-Slovenian relations as well. The Slovenian liberals from Trieste and Gorizia began to advocate the idea of a broader federalism, where the Habsburg Monarchy would have more than three federal units, while in the context of South Slavic relations they were inclined to Serbian state visions.

Keywords: Slovenian liberals, federalism, trialism, Habsburg Monarchy, Austrian Littoral 